Article

\title{
Establishing Sprinkling Requirements on Trailers Transporting Market Weight Pigs in Warm and Hot Weather
}

\author{
Rebecca Kephart ${ }^{1}$, Anna Johnson ${ }^{1, *}$, Avi Sapkota ${ }^{2}$, Kenneth Stalder ${ }^{1}$ and John McGlone ${ }^{2}$ \\ 1 Department of Animal Science, Iowa State University, Ames, IA 50011, USA; \\ E-Mails: rkdavis@iastate.edu (R.K.); stalder@iastate.edu (K.S.) \\ 2 Departments of Animal and Food Science and Animal Care Services, Texas Tech University, \\ Lubbock, TX 79409, USA; E-Mails: asapkota@purdue.edu (A.S.); john.mcglone@ttu.edu (J.M.) \\ * Author to whom correspondence should be addressed; E-Mail: johnsona@iastate.edu; \\ Tel.: +1-515-294-2098; Fax: +1-515-294-4471.
}

Received: 6 February 2014; in revised form: 25 March 2014 / Accepted: 4 April 2014 /

Published: 11 April 2014

Simple Summary: Transport is an inevitable process in the modern, multi-site swine industry. Pigs do not have efficient physiological means (such as sweating) to cool themselves. Therefore, being transported in hot weather can cause heat stress and even death. Sprinkling the pigs and/or bedding may facilitate cooling, thereby improving well-being and survivability of pigs arriving at the plant.

Abstract: This study was conducted July of 2012 in Iowa, in WARM $\left(<26.7^{\circ} \mathrm{C}\right)$ and HOT $\left(\geq 26.7^{\circ} \mathrm{C}\right.$ ) weather. Four sprinkling methods were compared, with one treatment being randomly assigned to each load: control- no sprinkling (not applied in HOT weather), pigs only, bedding only, or pigs and bedding. Experiment 1 used 51 loads in WARM- and 86 loads in HOT weather to determine sprinkling effects on pig measures (surface temperature, vocalizations, slips and falls, and stress signs). Experiment 2 used 82 loads in WARM- and 54 loads in HOT weather to determine the sprinkling effects on transport losses (non-ambulatory, dead, and total transport losses). Experiment 1 found that, in WARM weather, there were no differences between sprinkling treatments for surface temperature, vocalizations, or slips and falls $(p \geq 0.18)$. However, stress signs were $2 \%$ greater when sprinkling pigs- or bedding only- compared to control $(p=0.03)$. Experiment 2 found that, in WARM and HOT weather, sprinkling did not affect non-ambulatory, dead, or total transport losses $(p \geq 0.18)$. Although the current study did not find any observed sprinkling effects for pig measures or transport losses it is extremely important to note that 
the inference space of this study is relatively small, so further studies should be conducted to see if these results are applicable to other geographical regions and seasons.

Keywords: market-weight pig; sprinkling; transport loss; well-being

\section{Introduction}

Transporting swine is essential to the multi-site pork production. Around 113 million pigs were marketed in 2012 in the U.S. [1]. For pigs, marketing is a combination of potentially novel (defined as the first exposure), unfamiliar (defined as more than one exposure that is infrequent), and physically exerting experiences that could be perceived as stressful [2]. The term "transport losses" refers to pigs that become non-ambulatory (unable to keep up with the group and may have a structural injury) or are dead on arrival [2]. Increased transport losses and decreased meat quality may result if the pig is unable cope with these stressors [3-5].

The conditions under which pigs are handled and transported can have a direct impact on the pigs' well-being. In the U.S., trailers rely on passive ventilation, meaning air flow is dependent upon thermal buoyancy, movement of the vehicle itself, and the wind speed. To control the internal trailer environment, the National Pork Board's Transport Quality Assurance (TQA) program recommends that pigs $\left(>27{ }^{\circ} \mathrm{C}\right)$ and bedding $\left(>15^{\circ} \mathrm{C}\right)$ are sprinkled to facilitate evaporative cooling with the intention of reducing heat stress [6]. However, these recommendations are based on experiential information rather than scientific data [6]. Therefore, the objectives of these experiments were to compare the effects of sprinkling methods inside trailers on (1) market weight pig measures at the time of unloading and (2) transport losses at the plant.

\section{Experimental Section}

\subsection{General Procedures for Both Experiments}

The protocol for these experiments was approved by the Iowa State University Institutional Animal Care and Use Committee and data was collected during 3 weeks in July 2012.

\subsubsection{Animals, Farms, and Handling}

The company's loading crew sorted and moved market weight barrows and gilts from their home pen to the entrance of the loading ramp. The trucker moved the pigs up the loading ramp and onto the trailer. Both the loading crew and the trucker used a combination of sort boards, rattle paddles, and electric prods during loading (the number of times these devices were used was not recorded for these experiments).

Following TQA recommendations, any pig that became hot or stressed during loading would not have been loaded onto the truck. However, no pigs in these experiments met that criteria. The pigs were transported from commercial finishing facilities to a commercial processing plant, all located in Iowa. Transport occurred throughout the day and night. The trucker unloaded the pigs and plant 
personnel moved the pigs from the loading dock to the rest pens. During unloading, plant personnel and the trucker used paddles, rattles, and boards (the number of times these devices were used was not recorded for these experiments).

\subsubsection{Treatments and Experimental Design}

Treatment one (control) was defined as not sprinkling pigs or bedding on the trailer. Treatment two (pigs only) was defined as pigs being sprinkled after loading was completed for 6 to $8 \mathrm{~min}$. Treatment three (bedding only) was defined as bedding being sprinkled 4 to 6 min before the start of loading. Treatment four (pigs and bedding) was defined as both pigs and bedding being sprinkled for 6 to $8 \mathrm{~min}$. Due to concerns about pig well-being, the control treatment was not applied when the temperature was $\geq 26.7^{\circ} \mathrm{C}$. Therefore, two data sets will be presented: WARM (temperature $<26.7^{\circ} \mathrm{C}$; 4 treatments) and HOT $\left(\geq 26.7^{\circ} \mathrm{C} ; 3\right.$ treatments $)$ All treatments were applied by the researchers and were randomly assigned to trailers.

\subsubsection{Transport Trailers and Density}

All pigs were transported on aluminum drop deck (pot belly) trailers $17 \mathrm{~m}$ in length with diamond plate flooring. These were owned and operated by drivers employed by trucking companies contracted through the plant.

All compartments in the trailer were stocked according to the industry's current standard operating procedure of $0.41 \mathrm{~m}^{2} / \mathrm{pig}$ or $\sim 171 \mathrm{pigs} / \mathrm{load}$ [6]. The plant provided data on the number of pigs/trailer and the average weight of pigs on a trailer. For these experiments a density value was calucated and added to the statistical model because previous work has found density is an important variable in affecting animal based measures and transport losses [7-9].

Density $=[($ average pig weight per trailer $) \times($ pigs per trailer $)] /\left(\mathrm{m}^{2}\right.$ floor space in trailer $)$

\subsubsection{Temperature Humidity Index}

Ambient relative humidity and air temperature were measured at an airport $16.9 \mathrm{~km}$ from the plant. The airport data logger (1088 Hygrothermometer, Technical Service Laboratory, Fort Walton Beach, FL, USA) collected temperature and dew point. Relative humidity was then calculated from dew point and temperature measurements. The airport data logger was accurate for ambient temperature and for dew point $\pm 0.003{ }^{\circ} \mathrm{C}$. Ambient temperature $(\mathrm{T})$ and relative humidity $(\mathrm{RH})$ were used to calculate a temperature humidity index (THI) using the following equation [10]:

$$
\mathrm{THI}=\mathrm{T}-\left\{\left[0.55-\left(0.0055 \times \mathrm{RH}_{\text {decimal }}\right)\right](\mathrm{T}-14.5)\right\}
$$

This equation was found to fit the model of pig transport by Fitzgerald and others [7]. Additionally, other evidence suggests that it is important to consider both temperature and humidity when determining heat stress in pigs [11-13]. 


\subsection{Experiment 1: Effects of Sprinkling Inside Trailers Transporting Market Weight Pigs During WARM and HOT Weather on Pig Measures and Bedding Moisture at Unloading}

A total of 51 loads were used in WARM- and 86 loads were used in HOT weather. In WARM weather, the treatments were control $(n=24)$, pigs only $(n=13)$, bedding only $(n=7)$, and pigs and bedding $(n=7)$. In HOT weather, the treatments were pigs only $(n=41)$, bedding only $(n=18)$, and pigs and bedding $(n=27)$.

\subsubsection{Pig Measures}

Pig measures were collected on a random sample of pigs at unloading using live observation. A random sample of pigs was defined as ignoring the first $\sim 10$ pigs at the beginning of unloading, counting 50 pigs (group A), ignoring a further $\sim 10$ pigs, and counting another 50 pigs (group B). This provided 100 pigs/load. For groups A and B, the following pig measures were tallied: vocalizations, slips and falls, and stress signs. Vocalizations were defined as an extended sound of high amplitude and frequency produced with an open mouth [2]. Slips were defined as a knee or hock touching the ground; falls were defined as a pig's body touching the ground [14]. Slips and falls were tallied as a single measure. Stress signs were defined as open mouth breathing, muscle tremors, and red-blotchy skin [15]. Surface temperature was measured laterally near the midline on 5 randomly selected pigs from groups A and B (total of 10 pigs/load). Surface temperature was measured with a dual laser infrared thermometer (model 42570, Extech Instruments, Nashua, NH, USA) which was accurate to $\pm 1{ }^{\circ} \mathrm{C}$.

\subsubsection{Bedding Moisture}

A total of 8 fresh bedding samples and 140 used bedding samples were collected from trailers. Fresh samples (0 loads) were defined as bedding that had not been previously used for transporting pigs. A fresh bedding sample was $\sim 45 \mathrm{~g}$. After each trailer had unloaded at the plant, a used bedding sample, defined as bedding which had transported $\geq 1$ trailer loads of pigs was collected. Half of the used bedding was collected from the bottom trailer deck and the remainder was collected from the top deck. Each used bedding sample was $\sim 410 \mathrm{~g}$. Bedding samples were stored in a cardboard box at room temperature $\left(\sim 21^{\circ} \mathrm{C}\right)$ on the floor for no longer than $1 \mathrm{wk}$ after trial completion.

Bedding moisture was determined following standard operating procedure for drying samples. A tin measuring $7.6 \mathrm{~cm}$ wide by $2.2 \mathrm{~cm}$ deep (model A90, Wilkinson Industries Inc., Fort Calhoun, NE, USA) was weighed. Each bedding sample was kneaded by hand inside the closed storage bag for $\sim 30$ s. Two, 3 to $6 \mathrm{~g}$ subsamples (subsample A and B) were removed from the bag using a spoon. Subsample A was placed in one tin and subsample B was placed in a second. The bedding subsample in its respective tin was weighed (accurate $\pm 0.03 \mathrm{mg}$; model AT261 DeltaRange, Metler-Toledo GmBh Laboratory and Weighing Technologies, Greifensee, Switzerland) to determine wet weight. Bedding subsamples were dried for $\sim 20$ to $24 \mathrm{~h}$ at $100{ }^{\circ} \mathrm{C}$ in a convection oven (model DKN810, Yamato Scientific America Inc., Santa Clara, CA, USA). After drying, subsamples were re-weighed; this was defined as the dry weight. Moisture percent for each subsample was calculated using the following equation [16]: 


$$
\text { Moisture percent }=[(\text { dry weight }) /(\text { wet weight })] \times 100
$$

A standard deviation of moisture percentage between subsample A and subsample B and an average of the moisture percent of subsample A and subsample B were calculated. Between subsample A and subsample $\mathrm{B}$, the coefficient of variation $(\mathrm{CV})$ was calculated using the following equation:

$$
\mathrm{CV}=(\text { Standard deviation / average }) \times 100
$$

If the $C V \geq 10$ the sample was re-subsampled and dried a second time $(n=14)$. If the sample was still found to be too variable on the second drying, that samples were removed from the data set $(\mathrm{n}=0)$. The data from bedding moisture will be presented descriptively separated by the number of loads on the bedding, ranging from 0 to $\geq 4$ loads.

\subsubsection{Transport Events}

Researchers recorded the time that loading started and ended, the time the trailer left the farm, and the time that unloading started and ended. Processing plant records provided the arrival time of the trailer at the plant. Loading was defined as the time interval from the first pig's front foot stepped onto the trailer until the last pig's hind foot stepped onto the trailer. Wait time at the farm was defined as the time from when the last pig's hind foot stepped onto the trailer until the trailer left the farm. Transport was defined as the time interval from when trailer left the farm until the trailer arrived at the plant. Wait time at the plant was defined as the time interval from when the trailer arrived at the plant until the first pig's front foot stepped off the truck. Unloading was defined as the time interval from when the first pig's front foot stepped off the truck until the last pig's hind foot stepped off the truck. Total transit time was defined as the time from when the first pig's front foot stepped onto the trailer (start of loading) until the last pig's hind foot stepped off the trailer (end of unloading).

\subsubsection{Bedding Level}

The number of $0.2 \mathrm{~m}^{3}(22.7 \mathrm{~kg})$ bags of wood shaving bedding/trailer were recorded. Because trailers rely on passive ventilation, in the winter bedding is believed to insulate pigs from extreme cold. In the summer, less bedding is included as a means of providing traction and absorbing waste.

\subsection{Experiment 2: Effects of Sprinkling Inside Trailers on Market Weight Pig Transport Losses During WARM and HOT Weather}

A total of 82 loads were used in WARM- and 54 loads were used HOT weather to determine if sprinkling effected transport losses. In WARM weather, the treatments were control $(n=48)$, pigs only $(\mathrm{n}=11)$, bedding only $(\mathrm{n}=15)$, and bedding and pigs $(\mathrm{n}=8)$. In HOT weather, the treatments were pigs only $(n=31)$, bedding only $(n=9)$, and bedding and pigs $(n=14)$.

Transport Losses at the Plant

Plant employees identified non-ambulatory (sum of fatigued and injured) [2] and dead (sum of euthanized- and dead on arrival), Total transport losses were defined as the sum of non-ambulatory and dead. 


\subsection{Statistical Analysis}

For both experiments, data were evaluated for missing and erroneous values by using the filter feature in Excel (Microsoft Office 2010, Microsoft Redmond, WA, USA). The remaining analyses were completed using SAS software (SAS V 9.2 Institute Inc., Cary, NC, USA). Using the means and sort procedures data was checked for erroneous and potential outlier data points. Data that was identified as a potential outlier was checked against the original data. If correct it was simply highlighted in the excel data, if incorrect that value was substituted per the original data. Because all four treatments were only present when the temperature was $<26.7^{\circ} \mathrm{C} \mathrm{SAS}$ was used to create two data sets from the single excel file data was originally entered (WARM and HOT data sets). $p<0.05$ was considered significant for both experiments. $p \leq 0.10$ was considered tending for both experiments. For both experiments, each variable collected was evaluated on whether it should be present in the model. Variables that might have affected the pig measures were attempted in the model. Those variables that were found to be significant or were indicated by previous research to cause variation in pig transport were retained for the final model.

\subsubsection{Experiment 1: Effects of Sprinkling Inside Trailers Transporting Market Weight Pigs During WARM and HOT Weather on Pig Measures and Bedding Moisture at Unloading}

Because researchers sometimes counted more, or less than 50 pigs/group, data for vocalizations, slips and falls, and stress signs were analyzed as a percent of the pigs counted:

Percent pig measure $=[($ number of times a measure was counted $) /($ number pigs counted in that group $)] \times 100$

Furthermore, the SAS program (SAS 9.3, SAS Institute Inc., Cary, North Carolina) was used to create a new variable from the percent of vocalizations, slips and falls, and stress signs from group A and group B of 50 (e.g., [percent stress signs group A + percent stress signs group B]/2). Surface temperature was analyzed as an average of the 10 pigs measured per load.

Data were analyzed using a mixed model (PROC MIXED, SAS 9.3 SAS, Institute Inc., Cary, NC, USA) where the response variables, surface temperature, vocalizations, slips and falls, and stress signs, were analyzed using sprinkling treatment and bedding level as fixed effects, THI at unloading and density as linear covariates, and farm, trucking company, and researcher at the plant as random effects.

\subsubsection{Experiment 2: Effects of Sprinkling Inside Trailers on Market Weight Pig Transport Losses During WARM and HOT Weather}

Analysis of non-ambulatory-, dead-, and total transport losses per trailer was performed using a generalized linear mixed model (GLIMMIX procedure, SAS 9.3 Cary, NC, USA). The data approximated a Poisson distribution and was log transformed by the GLIMMIX procedure (SAS 9.3 Cary, NC, USA) prior to statistical analysis. The model used sprinkling treatment as a fixed effect, THI at loading and density as linear covariates, and farm and trucking company as random effects. The ILINK option (SAS 9.3 Cary, NC, USA) was used to back-transform least squares means into their original unit of measure for ease of interpretation. 


\section{Results and Discussion}

\subsection{Experiment 1: Effects of Sprinkling Inside Trailers Transporting Market Weight Pigs During WARM and HOT Weather on Pig Measures and Bedding Moisture at Unloading}

\subsubsection{Sprinkling}

In WARM weather, sprinkling treatment had no observed effect on surface temperature, vocalizations, or slips and falls $(p \geq 0.18)$. However, stress signs were $2 \%$ greater for the bedding and pig treatment than control ( $p=0.03$; Table 1). In HOT weather, sprinkling method had no effect on surface temperature, vocalizations, slips and falls, or stress signs ( $p \geq 0.19$; Table 1).

Table 1. Experiment 1. Effects of sprinkling ${ }^{1}$ on pig measures ${ }^{2}$ in market weight pigs in WARM $^{3}$ and HOT ${ }^{4}$ weather.

\begin{tabular}{|c|c|c|c|c|c|c|c|}
\hline \multirow{2}{*}{\multicolumn{2}{|c|}{$\begin{array}{l}\text { WARM weather, } \\
\text { measure }\end{array}$}} & \multicolumn{4}{|c|}{ Sprinkling treatment } & \multirow[b]{2}{*}{$p$-value } & \multirow[b]{2}{*}{$\mathbf{R}^{2}$} \\
\hline & & $\begin{array}{c}\text { Control } \\
\mathrm{n}=\mathbf{2 4}\end{array}$ & $\begin{array}{l}\text { Pigs only } \\
n=13\end{array}$ & $\begin{array}{c}\text { Bedding only } \\
\mathrm{n}=7\end{array}$ & $\begin{array}{l}\text { Bedding and pigs } \\
\qquad n=7\end{array}$ & & \\
\hline \multirow{2}{*}{\multicolumn{2}{|c|}{$\begin{array}{l}\text { Surface temperature, }{ }^{\circ} \mathrm{C} \\
\text { Vocalizations, \% of pigs } \\
\text { counted }\end{array}$}} & $32.2 \pm 0.5$ & $32.7 \pm 0.4$ & $33.1 \pm 0.6$ & $32.3 \pm 0.6$ & 0.18 & 0.41 \\
\hline & & $2.4 \pm 1.8$ & $2.6 \pm 1.8$ & $2.7 \pm 1.9$ & $3.4 \pm 1.9$ & 0.65 & 0.04 \\
\hline \multicolumn{2}{|c|}{$\begin{array}{l}\text { Slips and falls, \% of pigs } \\
\text { counted }\end{array}$} & $0.7 \pm 0.2$ & $0.5 \pm 0.2$ & $0.5 \pm 0.3$ & $0.2 \pm 0.3$ & 0.61 & 0.10 \\
\hline \multicolumn{2}{|c|}{$\begin{array}{l}\text { Stress signs, \% of pigs } \\
\text { counted }\end{array}$} & $0.6 \pm 0.4^{\mathrm{a}}$ & $0.5 \pm 0.4^{\mathrm{a}, \mathrm{b}}$ & $1.5 \pm 0.6^{\mathrm{a}, \mathrm{b}}$ & $2.6 \pm 0.6^{b}$ & 0.03 & 0.03 \\
\hline \multicolumn{2}{|c|}{ HOT weather } & $\mathbf{n}=\mathbf{0}$ & $n=41$ & $n=18$ & $\mathbf{n}=\mathbf{2 7}$ & & \\
\hline \multirow{2}{*}{\multicolumn{2}{|c|}{$\begin{array}{l}\text { Surface temperature, }{ }^{\circ} \mathrm{C} \\
\text { Vocalizations, \% of pigs } \\
\text { counted }\end{array}$}} & . & $35.3 \pm 0.3$ & $34.8 \pm 0.3$ & $34.9 \pm 0.3$ & 0.19 & 0.37 \\
\hline & & . & $1.7 \pm 1.2$ & $1.7 \pm 1.2$ & $2.0 \pm 1.2$ & 0.63 & 0.01 \\
\hline \multicolumn{2}{|c|}{$\begin{array}{l}\text { Slips and falls, \% of pigs } \\
\text { counted }\end{array}$} & . & $0.6 \pm 0.4$ & $0.9 \pm 0.4$ & $0.6 \pm 0.4$ & 0.51 & 0.05 \\
\hline \multicolumn{2}{|c|}{$\begin{array}{l}\text { Stress signs, \% of pigs } \\
\text { counted }\end{array}$} & . & $7.2 \pm 1.4$ & $6.0 \pm 1.6$ & $5.7 \pm 1.4$ & 0.35 & 0.31 \\
\hline \multicolumn{8}{|c|}{$\begin{array}{l}\text { Sprinkling methods, applied by researchers were: bed } \\
\text { watered down by the researcher for } 4-6 \text { min before th } \\
\text { after loading completed for } 6-8 \text { min when the bedding } \\
\text { and bedding (both pigs and bedding being watered). }\end{array}$} \\
\hline 2 & \multicolumn{7}{|c|}{$\begin{array}{l}\text { Pig measures were: surface temperature (measured laterally near the midline with a dual laser infrared } \\
\text { thermometer on } 10 \mathrm{pigs} / \mathrm{load} \text { ), vocalizations (an extended sound of high amplitude and frequency } \\
\text { produced with an open mouth [2], slips (a knee or hock touching the ground) and falls (a pig's body } \\
\text { touching the ground [14]) and stress signs (open mouth breathing, muscle tremors, and red-blotchy } \\
\text { skin [15]). }\end{array}$} \\
\hline 3 & \multicolumn{7}{|c|}{ Warm weather was defined as the temperature $<26.7^{\circ} \mathrm{C}$; based on 51 loads. } \\
\hline 4 & \multicolumn{7}{|c|}{ Hot weather was defined as the temperature $\geq 26.7^{\circ} \mathrm{C}$; based on 86 loads. } \\
\hline & & & & & & & \\
\hline
\end{tabular}


Pig vocalizations are a non-invasive measure and which may indicate the distress [17-19]. Kiley [17] has described 13 different types of pig vocalizations being expressed at different ages and within a variety of situations, for example social-greeting or non-social-startle. Furthermore, studies have found that squeal type vocalizations are associated with unpleasant situations [17,18,20]. Although vocalizations were not different in the context of this study between bedding levels, they may still be a useful non-invasive measure when assessing how pigs are coping with the transport process.

The current study observed surface temperature ranging $29.3{ }^{\circ} \mathrm{C}$ to $36.2{ }^{\circ} \mathrm{C}$ in WARM weather and $30.1{ }^{\circ} \mathrm{C}$ to $38.7^{\circ} \mathrm{C}$ in HOT weather (Figures 1 and 2). Although past research reported surface temperature for market weight pigs ranging between $38.6{ }^{\circ} \mathrm{C}$ to $39.5{ }^{\circ} \mathrm{C}[21,22]$, a review by Fox [23] in Canada reported that sprinkled pigs had 10\% lower surface temperature than those pigs which were not sprinkled. Based on the surface temperatures seen in this study, it seems pigs in this study were not heat stressed and in turn this may indicate that the pigs' physiological responses combined with the sprinkling treatments could be effective at mitigating heat stress.

\subsubsection{Bedding Moisture}

Fresh bedding averaged $\sim 5 \%$ moisture before any sprinkling treatments were applied. After sprinkling treatments had been applied and one load of pigs had been transported to the plant, bedding only and bedding and pigs sprinkling treatments had $\sim 5 \%$ more moisture than pigs only or control treatments. However, when $\geq 2$ loads had been transported, bedding moisture held constant at $\sim 65 \%$ regardless of sprinkling treatment (Table 2).

Table 2. Experiment 1. Bedding moisture ${ }^{1}$ by sprinkling method ${ }^{2}$ combined WARM ${ }^{3}$ and $\mathrm{HOT}^{4}$ weather.

\begin{tabular}{lcccccccc}
\hline & \multicolumn{8}{c}{ Sprinkling treatment } \\
\cline { 2 - 9 } & \multicolumn{9}{c}{ Control } & \multicolumn{7}{c}{ Bedding only } & \multicolumn{2}{c}{ Pigs only } & \multicolumn{3}{c}{ Bedding and pigs } \\
\cline { 2 - 9 } & \multicolumn{7}{c}{ Bedding moisture (\%) } \\
\hline Loads & Mean & SD & Mean & SD & Mean & SD & Mean & SD \\
\hline 0 & 5.5 & 1.5 & 3.7 &. & 7.6 & 5.3 & 4.5 &. \\
1 & 63.3 & 6.2 & 68.8 & 8.2 & 62.5 & 15.2 & 70.6 & 8.7 \\
2 & 63.2 & 5.4 & 65.4 & 5.2 & 63.6 & 11 & 73.1 & 9.4 \\
3 & 62.5 & 4.2 & 59.4 & 6.4 & 70.1 & 9.4 & 62.8 & 8.3 \\
$\geq 4$ & 60.6 & 2 & 61.7 & 7.3 & 70.7 & 5 & 68.4 & 5.3 \\
\hline
\end{tabular}

There were 27 samples collected from trailers given the control treatment: 0 loads, $\mathrm{n}=2 ; 1$ load, $\mathrm{n}=14$; 2 loads, $\mathrm{n}=6 ; 3$ loads, $\mathrm{n}=2$; and $\geq 4$ loads, $\mathrm{n}=3$. There were 58 samples taken from trailers given the pigs only treatment: 0 loads, $\mathrm{n}=1 ; 1$ load, $\mathrm{n}=26 ; 2$ loads, $\mathrm{n}=11 ; 3$ loads, $\mathrm{n}=11$; and $\geq 4$ loads, $\mathrm{n}=6$. There were 25 samples collected from trailers given the bedding only treatment: 0 loads, $\mathrm{n}=1 ; 1$ load, $\mathrm{n}=6 ; 2$ loads, $\mathrm{n}=9 ; 3$ loads, $\mathrm{n}=5$; and $\geq 4$ loads, $\mathrm{n}=4$. There were 38 samples taken from trailers given the pigs and bedding treatment: 0 loads, $\mathrm{n}=1 ; 1$ load, $\mathrm{n}=12 ; 2$ loads, $\mathrm{n}=10 ; 3$ loads, $\mathrm{n}=6$; and $\geq 4$ loads, $\mathrm{n}=9$. Bedding moisture was calculated by: [(dry bedding weight)/(wet bedding weight) $] \times 100$.

2 Sprinkling treatments were defined as: control (no water on pigs, bedding dry), pigs only (bedding dry, pigs watered for 6-8 min), bedding only (bedding already wet or bedding watered for 4-6 min), and bedding and pigs (both pigs and bedding wetted as previously described).

3 WARM weather was defined as $<26.7^{\circ} \mathrm{C}$; based on 50 loads.

4 HOT weather was defined as $\geq 26.7^{\circ} \mathrm{C}$; based on 92 loads. 
Lack of increasing moisture with subsequent loads suggests that only fresh bedding is effective at moisture absorbance. This study only observed trailers with wood shavings. Wood shavings are less absorbent than straw or corn stover (1.15 vs. 1.97 vs. 2.70 mean absorbency factor, respectively; [24,25]. Data from this study supports the TQA guidelines, suggesting trailers should be washed out and fresh bedding applied after every load [6], which may also help with better traction for the pigs [26], improve biosecurity [27] and may decrease stress [28-30]. However, individual company protocols vary on washout frequency and application of fresh bedding. Trailer wash out can range from $\$ 15$ to $\$ 190$ [31]. Annually, washing out trailers between each load and re-bedding the trailer has been estimated to cost $\sim \$ 8$ to $\$ 108$ million annually [32]. However, this estimate does not include potential lost income to the driver while washing the trailer or environmental implications for water usage and bedding disposal. In addition, using three instead of six bags in warm weather (defined as temperature ranging $16.1{ }^{\circ} \mathrm{C}$ to $43.4{ }^{\circ} \mathrm{C}$ ) has been estimated to save $\$ 13$ million [32]. Hence, adding the cost of washout, Kephart and others [32] found that using three bags/trailer and washing out after every load would cost between $\sim \$ 22$ and $\$ 121$ million annually. A cost benefit analysis for using fresh bedding after every load, in relation to overall swine well-being improvements is suggested.

\subsubsection{Transport Events}

The mean loading times in this study (Table 3) were similar to previous studies by Gesing and others [15] and Brown and colleagues [33] at $38 \mathrm{~min}$ and $45 \mathrm{~min}$ respectively. Mean unloading time in the current study was also similar to Gesing and others [15] at $18 \mathrm{~min}$. Transport time was about double for that reported by Gesing and others (59 min [15]), but comparable to Pilcher and others (107 min [34]). A possible explanation for this increased transport time in the current study was the distance between the farms and the plant (ranging from 74 to $296 \mathrm{~km}$ ). The plant used by Gesing and others [15] was $85 \mathrm{~km}$ from the farm. The wait time at the plant observed in this study was longer than that reported by Gesing and others (9 min [15]). However, Pilcher and colleagues [34] and Gesing and colleagues [35] reported a mean wait time of $\sim 21 \mathrm{~min}$. Wait time can be affected by a variety of factors such as time of arrival and labor availability at the plant. A wait of $\sim 20 \mathrm{~min}$ is very acceptable for the U.S. swine industry and within the context of this study was not detrimental to pig well-being. Transport event times will need to be carefully reviewed by trucking companies, processing facilities, and the truckers themselves due to changes made by the U.S. Department of Transportation (DOT). As of July 1st, 2013, the DOT hours-of-service safety regulation states that after $8 \mathrm{~h}$ of driving the trucker must take a 30 min break away from the truck [36]. For transportation of non-animate goods this will likely not be a challenge. However, if live animals are being transported, increased time when the trailer is stationary can result in an increased in both temperature and relative humidity [37]. 
Table 3. Experiment 1. Descriptive statistics for transport events ${ }^{1}$ for sprinkling method in market weight pigs for both $\mathrm{WARM}^{2}$ and $\mathrm{HOT}^{3}$ weather.

\begin{tabular}{lcccc}
\hline $\begin{array}{l}\text { WARM weather; } \\
\text { Event, min }\end{array}$ & Mean & SD $^{4}$ & Min $^{5}$ & Max $^{6}$ \\
\hline Loading & 32 & 12 & 14 & 65 \\
Wait time at farm & 7 & 6 & 2 & 42 \\
Transport & 156 & 43 & 63 & 280 \\
Wait time at plant & 15 & 13 & 1 & 50 \\
Unloading & 15 & 6 & 5 & 36 \\
Total time & 230 & 52 & 126 & 390 \\
\hline$\quad$ HOT weather & & & & \\
\hline Loading & 28 & 11 & 13 & 65 \\
Wait time at farm & 9 & 4 & 1 & 19 \\
Transport & 168 & 41 & 48 & 255 \\
Wait time at plant & 24 & 15 & 5 & 65 \\
Unloading & 24 & 15 & 5 & 65 \\
Total time & 238 & 62 & 56 & 369 \\
\hline
\end{tabular}

1 Transport events were loading (the time from when the first pig stepped on to the trailer until the last pig stepped onto the trailer), wait time at the farm (the time from when the last pig stepped onto the trailer until the trailer left the farm), transport (the time from when the trailer left the farm was closed until the truck arrived at the plant), wait time at the plant was defined as the time from when the truck arrived at the plant until the first pig stepped off), unloading (the time from the first pig stepped off the trailer until the last pig stepped off the trailer the trailer).

2 WARM weather was defined as $<26.7^{\circ} \mathrm{C}$; based on 50 loads.

3 HOT weather was defined as $\geq 26.7^{\circ} \mathrm{C}$; based on 92 loads.

$4 \quad$ SD abbreviation for standard deviation.

5 Min abbreviation for minimum.

$6 \quad$ Max abbreviation for maximum.

\subsubsection{Temperature Humidity Index}

In WARM and HOT weather, with increasing THI at unloading pig surface temperature increased ( $p<0.01$; Figures 1 and 2). In WARM weather, as THI increased from $\sim 17$ to 19 , surface temperature increased $\sim 7{ }^{\circ} \mathrm{C}$. In HOT weather, as THI increased from $\sim 20$ to 24 , surface temperature increased $\sim 9{ }^{\circ} \mathrm{C}$.

In WARM weather, no THI effects were observed at unloading on vocalizations, slips and falls, or stress signs $\left(p=0.19, \mathrm{R}^{2}=0.04 ; p=0.15, \mathrm{R}^{2}=0.10\right.$; and $p=0.44, \mathrm{R}^{2}=0.03$, respectively; data not presented). In HOT weather, there were no THI observed effects on vocalizations or slips and falls ( $p=0.96, \mathrm{R}^{2}=0.01 ; p=0.40, \mathrm{R}^{2}=0.05$; data not presented). 
Figure 1. Experiment 1. Effects of temperature humidity index (THI) at unloading on surface temperature of market weight pigs at unloading in WARM weather $\left(<26.7{ }^{\circ} \mathrm{C}\right.$; $\left.p<0.01, \mathrm{R}^{2}=0.41\right)$.

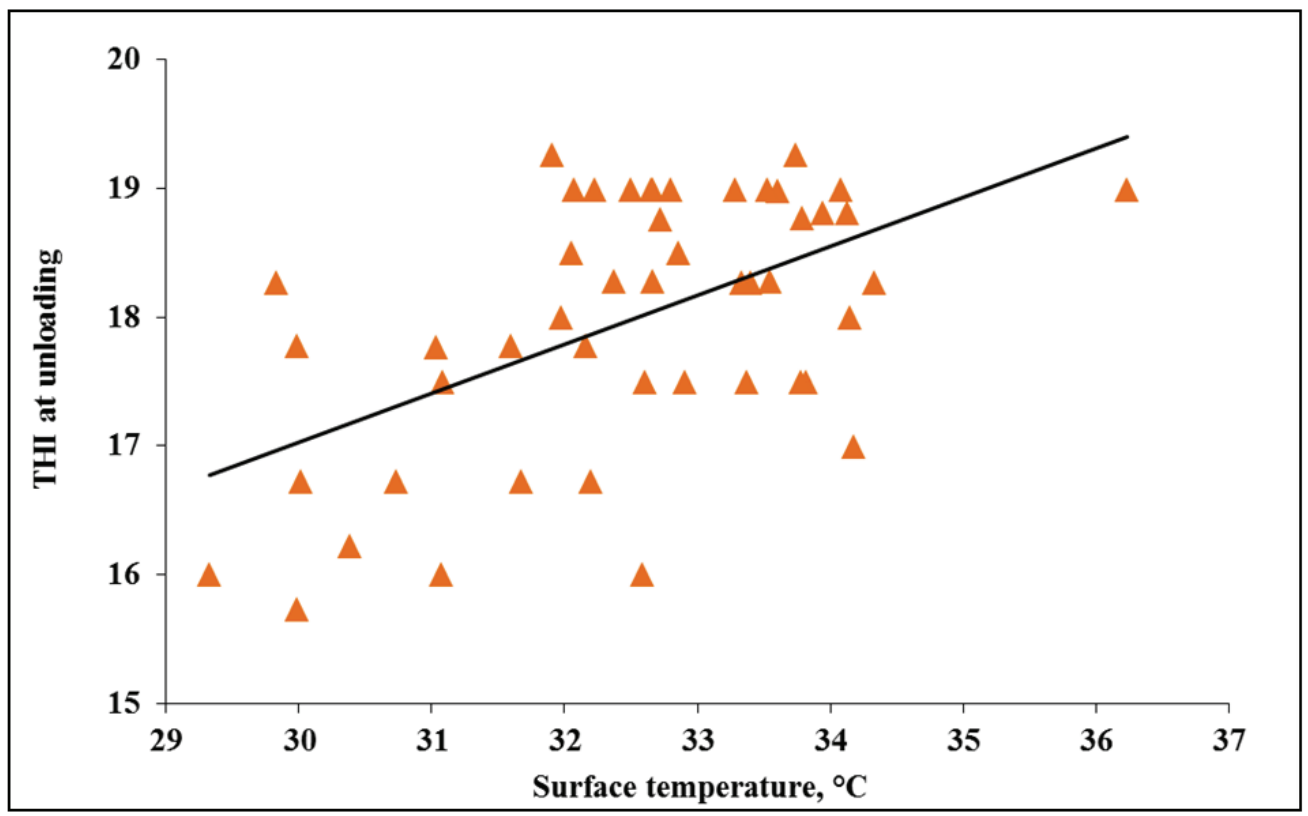

Figure 2. Experiment 1. Effects of THI at unloading on surface temperature of market weight pigs at unloading in HOT weather $\left(\geq 26.7^{\circ} \mathrm{C} ; p<0.01, \mathrm{R}^{2}=0.35\right)$.

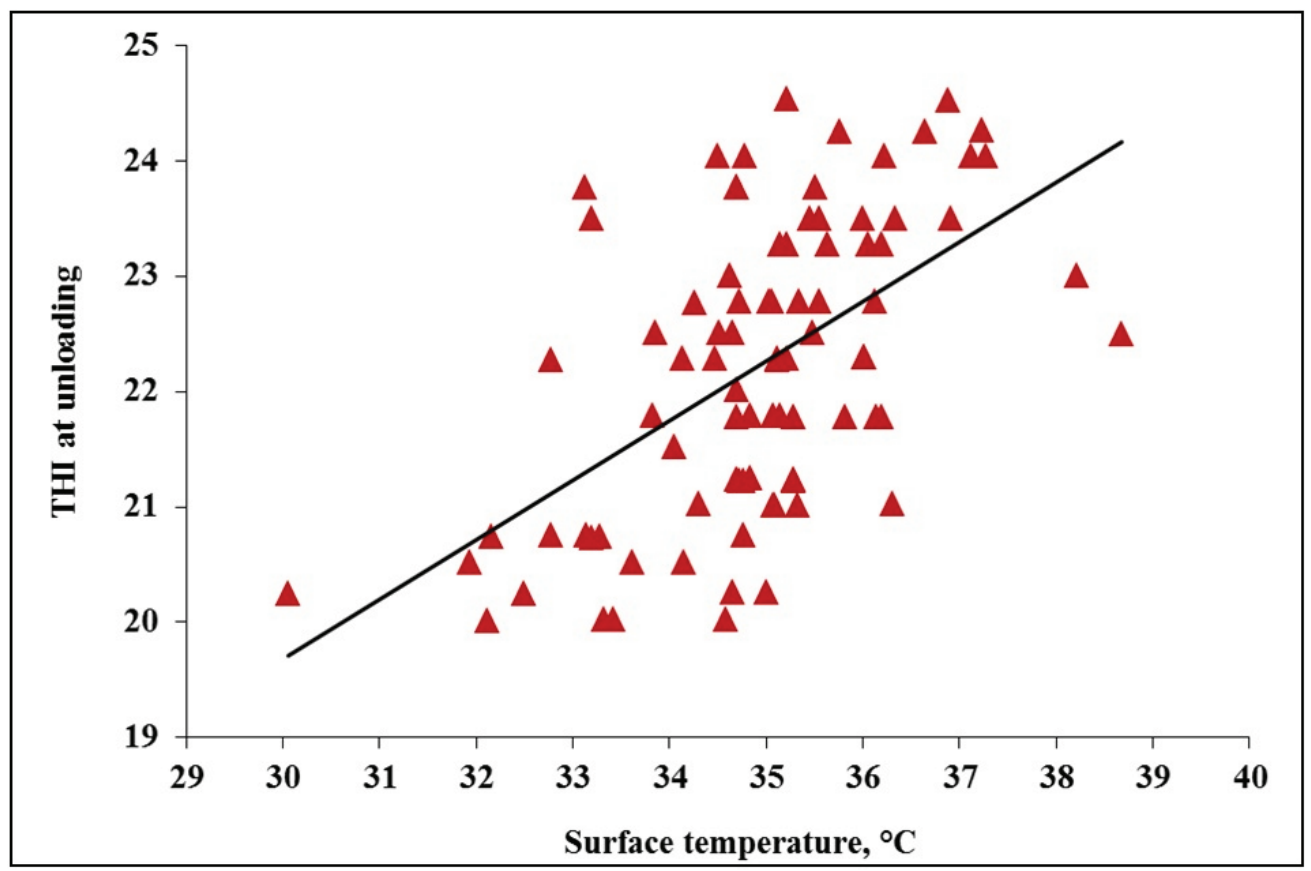

However, it was observed in HOT weather that as THI increased from 20 to 24 , stress signs at unloading increased $\sim 27 \%$ ( $p<0.01$, Figure 3). Increased stress signs, such as open mouth breathing and red blotchy skin, could be explained by the pig's natural heat coping mechanisms. Although surface temperature ranges seen in this study are not reflective of severely heat stressed pigs this may simply mean that their physiological mechanisms were acting effectively. It is difficult to speculate as 
to why an increase in THI would increase slips and falls. It may be that pigs are motivated to exit the trailer quicker and hence lose their footing more because of the heat in the trailer. However, this theory would need to be further evaluated in controlled heat and behavioral studies.

Figure 3. Experiment 1. Effects of THI at unloading on stress signs of market weight pigs at unloading in HOT weather $\left(\geq 26.7^{\circ} \mathrm{C} ; p<0.01, \mathrm{R}^{2}=0.31\right)$.

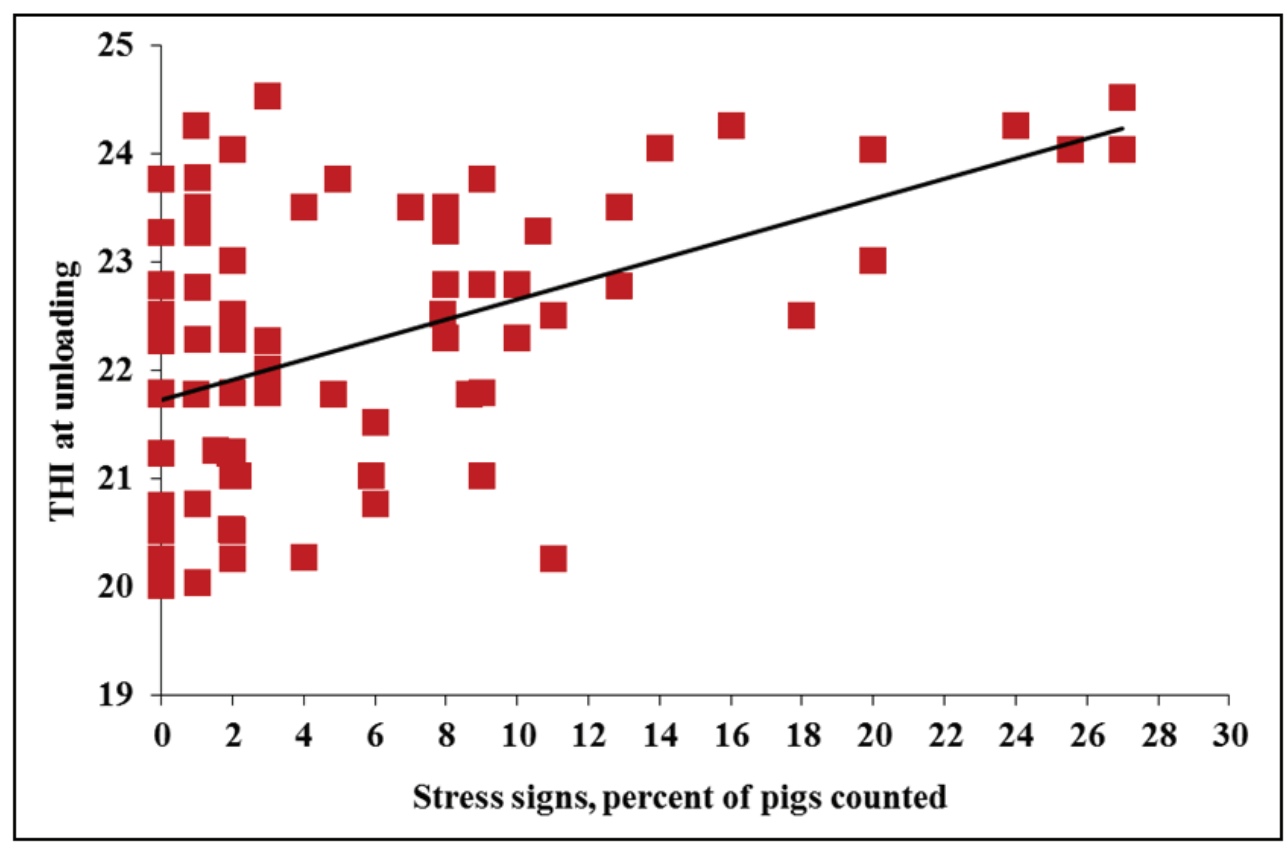

\subsubsection{Density}

In WARM weather, no density effects were observed on surface tempearture, vocalizations, slips and falls, or stress signs $\left(p=0.45, \mathrm{R}^{2}=0.41\right.$ and $p=0.39, \mathrm{R}^{2}=0.04 ; p=0.15, \mathrm{R}^{2}=0.10$; and $p=0.98$, $\mathrm{R}^{2}=0.03$, respectively; data not presented). In HOT weather, no effects of density were observed on surface temperature or vocalizations $\left(p=0.74, \mathrm{R}^{2}=0.37\right.$; and $p=0.36, \mathrm{R}^{2}=0.01$, respectively; data not presented).

In HOT weather as density increased from $\sim 275$ to $300 \mathrm{~kg} / \mathrm{m}^{2}$, slips and falls tended to decrease $\sim 5 \%\left(p=0.07, \mathrm{R}^{2}=0.10\right.$; data no presented) and stress signs tended to also decrease $\sim 27 \%(p=0.07$, $\mathrm{R}^{2}=0.03$; data no presented). Pigs in the current study were transported at an average density of 297 and $294 \mathrm{~m}^{2} /$ pig in WARM and HOT weather respectively, but the density equation used factored in weight and number of pigs on the trailer and was presented as a continous variable. This may be why the stress results in the current work disagree with Ritter and others [9] who reported that pigs transported at $0.52 \mathrm{~m}^{2} / \mathrm{pig}\left(\sim 252 \mathrm{~kg} / \mathrm{m}^{2}\right)$ had a higher incidence of skin discoloration than pigs transported at $0.39,0.42$, or $0.46 \mathrm{~m}^{2} / \mathrm{pig}\left(\sim 336,312\right.$, and $285 \mathrm{~kg} / \mathrm{m}^{2}$ respectively). Direct comparisons for changes in pig surface temperature based on density have not been published. Ritter and others [38] reported that density on the trailer had no effect on rectal temperature between $265 \mathrm{~kg} / \mathrm{m}^{2}\left(0.39 \mathrm{~m}^{2} / \mathrm{pig}\right)$ and $333 \mathrm{~kg} / \mathrm{m}^{2}\left(0.49 \mathrm{~m}^{2} / \mathrm{pig}\right) \mathrm{kg} / \mathrm{m}^{2}$ respectively. Chung and others noted as rectal temperature increased surface temperature increased in a linear manner [21]. This raises an interesting statistical discussion in regards to fixed effects and covariates, the use of both density and THI equations and in turn results, making comparison of these data sets challenging. 


\subsubsection{Bedding Level}

In WARM weather, no effects of bedding were observed on surface temperature, vocalizations, slips and falls, or stress signs ( $p \geq 0.12$; Table 4). In HOT weather, no effects of bedding were observed on vocalizations or slips and falls ( $p \geq 0.28$; Table 4$)$. However, in HOT weather, increasing bedding from two to three bags/trailer increased surface temperatures $0.6{ }^{\circ} \mathrm{C}$ and stress signs $2.5 \%$ ( $p \leq 0.05$; Table 4). This may indicate that in hot weather extra bedding may exacerbate heat stressed experienced by pigs on the trailer.

Table 4. Experiment 1. Effects of bedding level ${ }^{1}$ on pig measures ${ }^{2}$ in market weight pigs in $\mathrm{WARM}^{3}$ and $\mathrm{HOT}^{4}$ weather.

\begin{tabular}{|c|c|c|c|c|}
\hline \multirow[b]{2}{*}{ WARM weather; measures } & \multicolumn{2}{|c|}{ Bedding level } & \multirow[b]{2}{*}{$p$-value } & \multirow[b]{2}{*}{$\mathbf{R}^{2}$} \\
\hline & $\begin{array}{c}3 \\
n=41\end{array}$ & $\begin{array}{c}4 \\
n=10\end{array}$ & & \\
\hline Surface temperature, ${ }^{\circ} \mathrm{C}$ & $32.3 \pm 0.4$ & $32.9 \pm 0.6$ & 0.12 & 0.41 \\
\hline Vocalizations, $\%$ of pigs counted & $3.0 \pm 1.7$ & $2.6 \pm 1.8$ & 0.59 & 0.04 \\
\hline Slips and falls, $\%$ of pigs counted & $0.5 \pm 0.2$ & $0.4 \pm 0.3$ & 0.72 & 0.10 \\
\hline Stress signs, $\%$ of pigs counted & $1.1 \pm 0.3$ & $1.5 \pm 0.5$ & 0.42 & 0.03 \\
\hline HOT weather & $\mathrm{n}=\mathbf{6 7}$ & $\mathbf{n}=19$ & & \\
\hline Surface temperature, ${ }^{\circ} \mathrm{C}$ & $34.7 \pm 0.2$ & $35.3 \pm 0.3$ & 0.05 & 0.37 \\
\hline Vocalizations, $\%$ of pigs counted & $1.9 \pm 1.2$ & $1.7 \pm 1.2$ & 0.56 & 0.01 \\
\hline Slips and falls, $\%$ of pigs counted & $0.7 \pm 0.4$ & $0.6 \pm 0.4$ & 0.77 & 0.05 \\
\hline Stress signs, $\%$ of pigs counted & $5.1 \pm 1.3$ & $7.6 \pm 1.6$ & 0.03 & 0.31 \\
\hline \multicolumn{5}{|c|}{ Bedding level is the number of $\sim 0.2 \mathrm{~m}^{3}(22.7 \mathrm{~kg})$ bags of wood shavings/trailer. } \\
\hline \multicolumn{5}{|c|}{$\begin{array}{l}\text { Pig measures were: surface temperature (measured laterally near the midline with a dual laser infrared } \\
\text { thermometer on } 10 \text { pigs/load), vocalizations (extended sounds of high amplitude and frequency produced } \\
\text { with an open mouth [2]), slips and falls (a knee, hock, or body touching the ground [14]), and stress signs } \\
\text { (open mouth breathing, muscle tremors, and red-blotchy skin [15]). }\end{array}$} \\
\hline \multicolumn{5}{|c|}{ WARM weather was defined as the temperature $<26.7^{\circ} \mathrm{C}$; based on 48 loads. } \\
\hline
\end{tabular}

\subsection{Experiment 2: Effects of Sprinkling Inside Trailers on Market Weight Pig Transport Losses} During WARM and HOT Weather

\subsubsection{Sprinkling}

In WARM weather, the one non-ambulatory pig was from a trailer allocated to the pigs and bedding sprinkling treatment. In WARM and HOT weather, no effect of sprinkling treatment was observed for non-ambulatory, dead, or total transport losses ( $p \geq 0.18$; Table 5). It is important to note that total transport losses in the present study were $\sim 0.17$ pigs/trailer or $\sim 0.10 \%$. Additionally, when comparing the total transport loses percentages from the present study with losses on a national level, the estimated national average for total losses was $0.69 \%$ [38]. If a higher rate of losses were seen in this study there may have been bigger differences between the treatments allowing for significance. 
Table 5. Experiment 2. Effects of sprinkling ${ }^{1}$ on transport losses ${ }^{2}$ in market weight pigs in WARM ${ }^{3}$ and $\mathrm{HOT}^{4}$ weather.

\begin{tabular}{|c|c|c|c|c|c|c|}
\hline \multirow{2}{*}{$\begin{array}{l}\text { WARM weather; } \\
\text { transport losses, } \\
\text { pigs/trailer }\end{array}$} & \multicolumn{4}{|c|}{ Sprinkling Treatment } & \multirow[b]{2}{*}{$p$-value } & \multirow[b]{2}{*}{$\mathbf{R}^{2}$} \\
\hline & $\begin{array}{c}\text { Control } \\
\mathrm{n}=48\end{array}$ & $\begin{array}{c}\text { Pigs only } \\
\mathrm{n}=11\end{array}$ & $\begin{array}{l}\text { Bedding only } \\
\quad \mathrm{n}=15\end{array}$ & $\begin{array}{c}\text { Pigs and bedding } \\
n=8\end{array}$ & & \\
\hline Non-ambulatory & . & . & . & . & . & . \\
\hline Dead & $0.06 \pm 0.04$ & $0.13 \pm 0.11$ & $0.11 \pm 0.09$ & $0.00 \pm 0.00$ & 0.76 & 0.01 \\
\hline Total transport losses & $0.06 \pm 0.04$ & $0.24 \pm 0.15$ & $0.13 \pm 0.10$ & $0.00 \pm 0.01$ & 0.33 & 0.03 \\
\hline HOT weather & $\mathbf{n}=\mathbf{0}$ & $\mathbf{n}=\mathbf{3 1}$ & $\mathbf{n}=\mathbf{9}$ & $\mathrm{n}=14$ & & \\
\hline Non-ambulatory & . & $0.07 \pm 0.04$ & $0.00 \pm 0.00$ & $0.01 \pm 0.02$ & 0.28 & 0.32 \\
\hline Dead & . & $0.37 \pm 0.10$ & $0.21 \pm 0.14$ & $0.16 \pm 0.09$ & 0.31 & 0.27 \\
\hline Total transport losses & . & $0.45 \pm 0.11$ & $0.18 \pm 0.12$ & $0.19 \pm 0.10$ & 0.18 & 0.35 \\
\hline
\end{tabular}

$1 \quad$ Sprinkling methods, applied by researchers were: Control (no water sprinkled and bedding dry; not applied in HOT weather), bedding only (bedding already being damp or wetted for 4-6 min before the start of loading), pigs only (pigs being wetted after loading completed for 6-8 min when the bedding was dry), pigs and bedding (both pigs and bedding being watered).

2 Transport losses were non-ambulatory (sum of fatigued and injured pigs), dead (sum of euthanized- and dead on arrival), and total transport losses (sum of non-ambulatory and dead).

3 WARM weather was defined as the temperature $<26.7^{\circ} \mathrm{C}$; based on 79 loads.

4 HOT weather was defined as the temperature $\geq 26.7^{\circ} \mathrm{C}$; based on 49 loads.

\subsubsection{Temperature Humidity Index}

In WARM weather, the one non-ambulatory pig occurred when THI was 18 . In WARM weather, no THI at loading effects were observed were observed on dead or total transport losses $(p=0.94$, $\mathrm{R}^{2}=0.01 ; p=0.90, \mathrm{R}^{2}=0.03$; data not presented). In HOT weather, no THI effects were observed at loading on non-ambulatory, dead, or total transport losses $\left(p=0.66, \mathrm{R}^{2}=0.32 ; p=0.12, \mathrm{R}^{2}=0.27\right.$; $p=0.19, \mathrm{R}^{2}=0.35$; data not presented). Pigs in the current study were only transported in the summer months. This may explain why the results differ from Fitzgerald and colleagues [7] who observed more pigs than the current study in all seasons. Fitzgerald and colleagues reported [7] increased total transport losses as both THI and density increased. Additionally, they observed higher numbers of transport losses (1.41 total transport losses pigs/trailer) than were observed in the current study (in WARM 0.14 total transport losses pigs/load; in HOT weather 0.25 total transport losses pigs/load). It is difficult to compare the results found in the current study with other studies because other studies use temperature and relative humidity separately rather than in as an index [8,34,38,39].

\subsubsection{Density}

In WARM weather, the one non-ambulatory occurred on a trailer with a density of $291 \mathrm{~kg} / \mathrm{m}^{2}$. In WARM weather, no effects of density were observed on dead or total transport losses $(p=0.86$, $\mathrm{R}^{2}=0.01 ; p=0.81, \mathrm{R}^{2}=0.03$; data not presented). In HOT weather, no effects of density were observed on non-ambulatory pigs ( $p=0.01, \mathrm{R}^{2}=0.32$; Figure 4$)$. In HOT weather, decreasing density from $\sim 300$ to $265 \mathrm{~kg} / \mathrm{m}^{2}$ increased dead pigs/trailer by 2 ( $p=0.01$; Figure 5 ). In HOT weather, decreasing density from $\sim 300$ to $240 \mathrm{~kg} / \mathrm{m}^{2}$ increased total transport losses by four pigs/trailer 
$(p<0.01$; Figure 6$)$. However the relationship between both dead and total transport losses and density was weak $\left(\mathrm{R}^{2}=0.27\right.$ and $\mathrm{R}^{2}=0.35$, respectively). It is difficult to explain why dead and total transport losses increased with decreasing density, but pigs in this study were transported at similar density ranges compared to previous studies [7-9].

Figure 4. Experiment 2. Effects of density on trailers on non-ambulatory pigs per trailer in market weight pigs at unloading in $\mathrm{HOT}$ weather $\left(\geq 26.7^{\circ} \mathrm{C} ; p=0.01, \mathrm{R}^{2}=0.32\right)$.

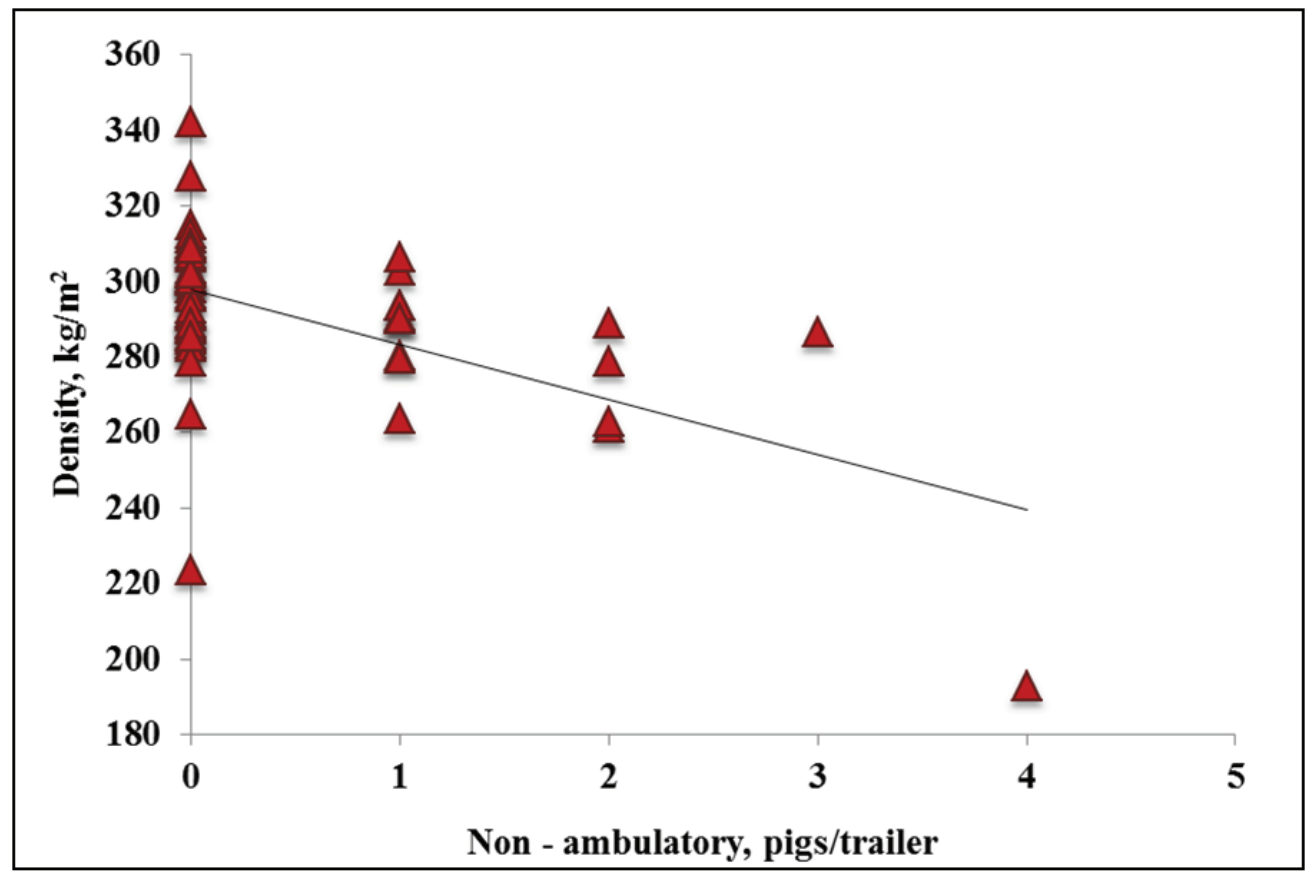

Figure 5. Experiment 2. Effects of density on trailers on dead pigs per trailer in market weight pigs at unloading in HOT weather $\left(\geq 26.7{ }^{\circ} \mathrm{C} ; p=0.01, \mathrm{R}^{2}=0.27\right)$.

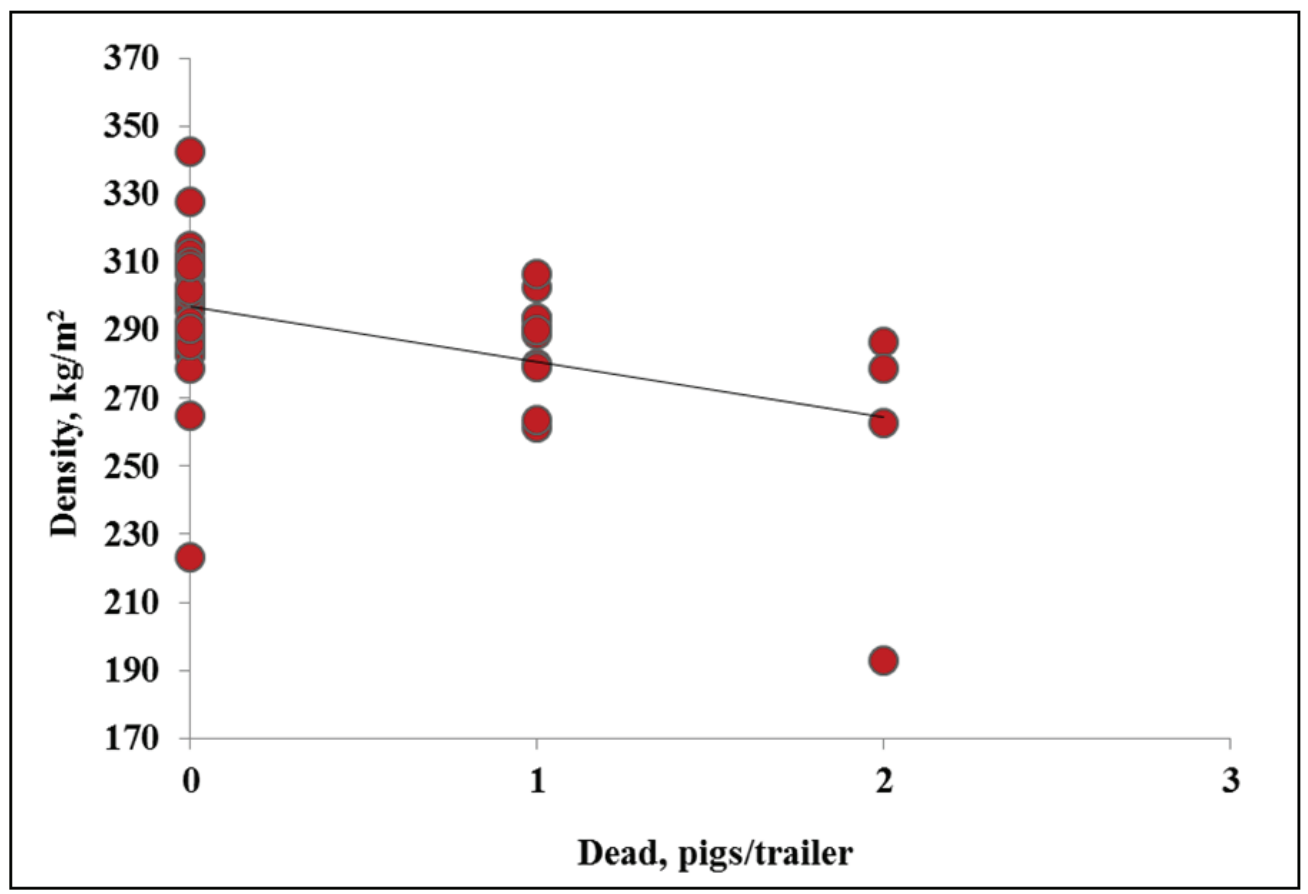


Figure 6. Experiment 2. Effects of density on trailers on total transport losses pigs per trailer in market weight pigs at unloading in HOT weather $\left(\geq 26.7^{\circ} \mathrm{C} ; p<0.01, \mathrm{R}^{2}=0.36\right)$.

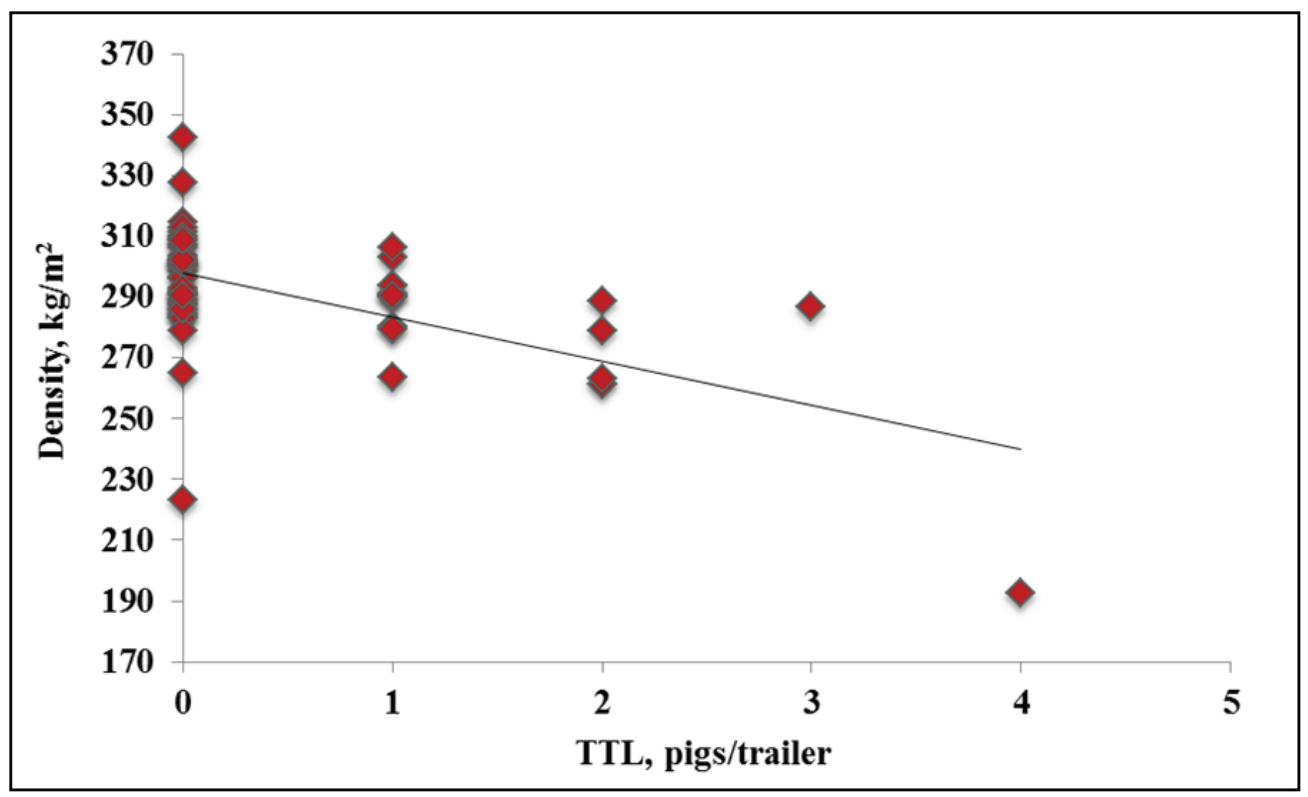

The current study reviewed a relatively small number of loads compared to past studies $[7,8]$ and also observed a lower rate of transport losses [7-9] than previous work. This may explain why the results in the current study disagree with past studies. Pilcher and colleagues [34] found no effects of density on dead or total losses in pigs transported in November, December, May, and June. However, Pilcher and colleagues used density as a treatment and it was fixed rather than continous. Fitzgerald and colleagues [7] predicted that total transport losses would increase constantly as density increased. Ritter and colleagues [8] found that increasing density increased non-ambulatory and total transport losses. Ritter and others [9] reported increasing density increased non-ambulatory and total transport losses.

\section{Conclusions}

Stressors during transportation have been shown to be additive [7,40]. Therefore, reducing or preventing stressors may improve pig well-being. A variety of factors may influence animal based measures indicative of well-being and transport losses in the market weight pigs. Although the current study did not find any observed sprinkling effects for pig measures or transport losses it is extremely important to note that the inference space of this study is relatively small (July in Iowa), so further studies should be conducted to see if these results are applicable to other geographical regions and seasons. 


\section{Acknowledgments}

Thank you to the plant and farms that participated, to the National Pork Board's Pork Checkoff program for funding, to Adrianne Kaiser, Avi Sapkota, David Smith, Jordann Wenzel, Kimberly Guay, and Rebecca Moest for data collection and to Nicholas Gabler for use of lab facilities and Martha Jeffery for assistance in the lab.

\section{Author Contributions}

J.M. and A.J. designed the experiment and had creative input into the writing. K.S. oversaw the statistical analysis and had creative input into the writing. R.K. collected the field data, conducted the statistical analysis and was the primary author on this paper. A.S. collected the field data and had creative input into the writing.

\section{Conflicts of Interest}

The authors declare no conflict of interest.

\section{References and Notes}

1. National Agriculture Statistics Service. Statistics by Subject: National Statistics for Hogs 2007-2012. 2013. Available online: http://www.nass.usda.gov/StatisticsbySubject/result.php? E9F60C8F-1297-3C82-AA04-BE07020602E\&sector=ANIMALS\%20\%26\%20PRODUCTS\& group=LIVESTOCK\&comm=HOGS (accessed on 15 June 2013).

2. Johnson, A.K.; Gesing, L.M.; Ellis, M.; McGlone, J.J.; Berg, E.; Lonergan, S.M.; Fitzgerald, R.; Karriker, L.A.; Ramirez, A.; Stalder, K.J.; Sapkota, A.; Kephart, R.; Selsby, J.T.; Sadler, L.J.; Ritter, M.J. Farm and pig factors affecting welfare during the marketing process. J. Anim. Sci. 2013, 91, 2481-2491.

3. Benjamin, M.E.; Gonyou, H.W.; Ivers, D.J.; Richardson, L.F.; Jones, D.J.; Wagner, J.R.; Seneriz, R.; Anderson, D.B. Effect of animal handling method on the incidence of stress response in market swine in a model system. J. Anim. Sci. 2001, 79, 279.

4. Hamilton, D.N.; Ellis, M.; Bertol, T.M.; Miller, K.D. Effects of handling intensity and live weight on blood acid-base status in finishing pigs. J. Anim. Sci. 2004, 82, 2405-2409.

5. Bertol, T.M.; Ellis, M.; Ritter, M.J.; McKeith, F.K. Effect of feed withdrawal and handling intensity on longissimus muscle glycolytic potential and blood measurements in slaughter weight pigs. J. Anim. Sci. 2005, 83, 1536-1542.

6. National Pork Board. Transport Quality Assurance Handbook, Version 4. Available online: http://www.pork.org/filelibrary/TQA/manual.pdf (accessed on 3 August 2011).

7. Fitzgerald, R.F.; Stalder, K.J.; Matthews, J.O.; Schultz-Kaster, C.M.; Johnson, A.K. Factors associated with fatigue, injured, and dead pig frequency during transport and lairage at a commercial abattoir. J. Anim. Sci. 2009, 87, 1156-1166. 
8. Ritter, M.J.; Ellis, M.; Brinkmann, J.; DeDecker, J.M.; Keffaber, K.K.; Kocher, M.E.; Peterson, B.A.; Schlipf, J.M.; Wolter, B.F. Effect of floor space during transport of market-weight pigs on the incidence of transport losses at the packing plant and the relationships between transport conditions and losses. J. Anim. Sci. 2006, 84, 2856-2864.

9. Ritter, M.J.; Ellis, M.; Brinkmann, J.; DeDecker, J.M.; Keffaber, K.K.; Kocher, M.E.; Peterson, B.A.; Schlipf, J.M.; Wolter, B.F. Effects of distance moved during loading and floor space on the trailer during transport on losses of market weight pigs on arrival at the packing plant. J. Anim. Sci. 2007, 85, 3454-3461.

10. National Oceanic and Atmospheric Association. Livestock Hot Weather Stress; U.S. Government Printing Office: Washington, DC, USA, 1976.

11. Agricultural and Biosystems Engineering. 2002. Livestock/poultry heat stress index and recommended management actions. Available online: http://www3.abe.iastate.edu/livestock/ heat_stress.asp (accessed on 16 July 2013).

12. Ingram, D.L. Stimulation of cutaneous glands in the pig. J. Comp. Physiol. 1967, 77, 91-113.

13. Ingram, D.L. Adaptations to ambient temperature in growing pigs. Pflugers Archiv-Eur. J. Physiol. 1977, 367, 257-264.

14. American Meat Institute. Recommended animal handling guidelines auditing guide: A systematic approach to animal welfare. 2012. Available online: http://www.animal handling.org/ht/a/ GetDocumentAction/i/80009 (accessed on 1 November 2011).

15. Gesing, L.M.; Johnson, A.K.; Selsby, J.T.; Abrams, S.; Hill, H.; Whitley, A.; Faga, A.; Bailey, R.; Stalder, K.J.; Ritter, M.J. Effects of grow-finish group size on stress responses at loading and unloading and the effect on transport losses from market-weight pigs. Prof. Anim. Sci. 2011, 27, 477-484.

16. Peters, J.; Combs, S.M.; Hoskins, B.; Jarman, J.; Kovar, J.L.; Watson, M.E.; Wolf, A.M.; Wolf, N. Recommended Methods of Manure Analysis; Cooperative Extension Publishing Operations: Madison, WI, USA, 2003.

17. Kiley, M. The vocalizations of ungulates, their causation and functions. Zeitschrift für Tierpsychologie 1972, 31, 171-222.

18. Xin, H.; DeShazer, A.; Leger, D.W. Pig vocalizations under selected husbandry practices. Trans ASAE 1990, 32, 2181-2184. Available online: http://digitalcommons.unl.edu/cgi/viewcontent.cgi? article $=1533 \&$ context $=$ psychfacpub $($ accessed on 10 October 2013$)$.

19. Manteuffel, G.; Puppe, B.; Schön, P.C. Vocalization of farm animals as a measure of welfare. Appl. Anim. Behav. Sci. 2004, 88, 163-182.

20. Tallet, C.; Špinka, M.; Maruščáková, I.; Šimeček, P. Human perception of vocalizations of domestic piglets and modulation by experience with domestic pigs (Sus scrofa). J. Comp. Psyc. 2010, 124, 81-91.

21. Chung, T.; Jung, W.; Nam, E.; Kim, J.; Park, S.; Hwang, C.Y. Comparison of rectal and infrared thermometry for obtaining body temperature of gnotobiotic piglets in conventional portable germ free facility. Asian-Aust. J. Anim. Sci. 2010, 23, 1364-1368.

22. Managing and treating the sick pig. 2013. Available online: http://www.thepigsite.com/pighealth/ article/48/managing-and-treating-the-sick-pig (accessed on 5 November 2013). 
23. Fox, J.L. The effect of water sprinkling market weight pigs transported during summer on pig behavior, gastrointestinal tract temperature, and trailer micro-climate. 2013. Available online: https://atrium.lib.uoguelph.ca/xmlui/bitstream/handle/10214/5279/Fox_Jessica_201301_Msc.pdf? sequence $=3$ (accessed on 29 July 2013).

24. Voyles, R.; Honeyman, M.S. Absorbency of alternative livestock bedding sources. 2006. Available online: http://lib.dr.iastate.edu/ans_air/vol652/iss1/59/(accessed on 1 July 2013).

25. McGlone, J.J.; Pond, W.G. Pig Production: Biological Principles and Applications; Delmar Learning: Clifton Park, NY, USA 2002; p. 309.

26. Sutherland, M.A.; McDonald, A.; McGlone, J.J. Effects of variations in the environment, length of journey, and type of trailer on the mortality and morbidity of pigs being transported to slaughter. Vet. Rec. 2009, 165, 13-18.

27. Environmental Contamination on the Farm. 2002. Available online: http://www.thepigsite.com/ pighealth/article/628/environmental-contamination-on-the-farm (accessed on 28 June 2013).

28. Amory, J.R.; Pearce, G.P. Alarm pheromones in urine modify the behavior of weaner pigs. Anim. Welf. 2000, 9, 167-175.

29. Grandin, T. Animal welfare in slaughter plants. In Proceedings of the 29th Annual Convention of the American Association of Bovine Practitioners, San Diege, CA, USA, 12-14 September 1996.

30. Wyatt, T.D. Pheromones and animal behavior. 2003. Available online: http://catdir.loc.gov/catdir/ samples/cam033/2002024628.pdf (accessed on 15 July 2013).

31. Livestock Network. Livestock Washouts. 2013. Available online: http://www.livestocknetwork.com/ Livestock_Washouts/ (accessed on 2 August 2013).

32. Kephart, R.K.; Johnson, A.K.; Stalder, K.J.; Huiatt, T.W.; Sapkota, A.; McGlone, J.J. Costs of Bedding on the Trailer, Trailer Wash out, and Transport Losses in Market Weight Pigs. 2014, in preparation.

33. Brown, J.; Stevens, T.; Gonyou, H.W. Loading facilities for market hogs. Saskatchewan's top 10. Prairie Swine Centre Annual Report 2011. Available online: http://www.prairieswine.com/ wp-content/uploads/2011/07/Annual-Report-2011.pdf (accessed on 20 May 2013).

34. Pilcher, C.M.; Ellis, M.; Rojo-Gómez, A.; Curtis, S.E.; Wolter, B.F.; Peterson, C.M.; Peterson, B.A.; Ritter, M.J.; Brinkmann, J. Effects of floor space during transport and journey time on indicators of stress and transport losses of market-weight pigs. J. Anim. Sci. 2011, 89, 3809-3818.

35. Gesing, L.M. Pre-sorting and pen size effects on the stress responses at loading and unloading and transport losses in market weight pigs. M.S. Thesis, Iowa State University, Ames, IA, USA, 2010.

36. United States Department of Transportation. http://www.fmcsa.dot.gov/rules-regulations/topics/ hos/statement.aspx (accessed on 12 June 2013).

37. Ellis, M.; Wang, X.; Funk, T.; Wolter, B.; Murphy, C.; Lenkaitis, A.; Sun, Y.; Pilcher, C. Development of Improved Trailer Designs and Transport Management Practices that Create the Optimum Environment for Market Weight Pigs During Transport and Minimize Transport Losses; National Pork Board Pork Checkoff Animal Welfare Research Report; National Pork Board: Des Moines, IA, USA, 2008. 
38. Ritter, M.J.; Ellis, M.; Anderson, D.B.; Curtis, S.E.; Keffaber, K.K.; Killefer, J.; McKeith, F.K.; Murphy, C.M.; Peterson, B.A. Effects of multiple concurrent stressors on rectal temperature, blood acid-base status, and longissimus muscle glycolytic potential in market-weight pigs. J. Anim. Sci. 2009, 87, 351-362.

39. Kephart, K.B.; Harper, M.T.; Raines, C.R. Observations of market pigs following transport to a packing plant. J. Anim. Sci. 2010, 88, 2199-2203.

40. Grandin, T.; Schultz-Kaster, C. Handling pigs. Available online: http://www.porkgateway.org/ FileLibrary/PIGLibrary/Factsheets/a6635v1-0.pdf (accessed on 29 July 2013).

(C) 2014 by the authors; licensee MDPI, Basel, Switzerland. This article is an open access article distributed under the terms and conditions of the Creative Commons Attribution License (http://creativecommons.org/licenses/by/3.0/). 